S.V. Felonenko, V.V. Gubkina

\title{
THE STABILITY RESEARCH OF COMPLETE HYDRAULIC SECTIONS OF MECHANIZED ROOF SUPPORT
}

Ways to improve the section sustainability of the complete mechanical hydraulic roof supports are analyzed. Theoretical and graphical relations of the stability margin sections for the complete roof supports in dependence with the extractive production angle while different motion schemes are obtained.

\section{ДОСЛІДЖЕННЯ СТІЙКОСТІ СЕКЦІЙ КОМПЛЕКТНОГО ГІДРАВЛІЧНОГО МЕХАНІЗОВАНОГО КРІПЛЕННЯ}

Виконано аналіз напрямів підвищення стійкості секцій комплектного механізованого гідравлічного кріплення, одержано теоретичні та графічні залежності запасу стійкості секцій комплектного кріплення від кута нахилу добувної виробки при різних схемах їх переміщення.

\section{ИССЛЕДОВАНИЕ УСТОЙЧИВОСТИ СЕКЦИЙ КОМПЛЕКТНОЙ ГИДРАВЛИЧЕСКОЙ МЕХАНИЗИРОВАННОЙ КРЕПИ}

Выполнен анализ направлений повышения устойчивости секций комплектной механизированной гидравлической крепи, получены теоретические и графические зависимости запаса устойчивости секций комплектной крепи от угла наклона очистной выработки при различных схемах их передвижки.

\section{INTRODUCTION}

Mechanization of stoping works in coal mines is carried out due to extended applying of complexes and aggregates. Powered hydroficated roof support performing a number of technical functions among which working support is the main one being considered as a basic complex machine and aggregate. Powered roof support is a completely new type of mining machines equipped with extensional and special hydro drive comprising a pump of permanent performance and the system of cylinders consuming power energy. Earlier mineral oils were used as working liquids in the hydro drive systems of mechanized roof support. Then mineral oils were changed for noncombustible and less expensive liquids. At present powered roof support is defined as a mining machine disposed along the whole length of a mining face and composed of selfadvanced sections. The roof support is served for supporting side rocks and keeping stoping face in safe and working conditions. It provides mechanizing support processes, roof control and moving a face conveyer and complex base along with a winning machine.

A powered support consists of a highly strained steel construction in terms of power relation ensuring the maintenance of the roof rocks by the system of hydraulic props and providing compliant resistance to roof rocks subsidence. Hydraulic advancing cylinders of support roof and face conveyer flight along with a winning machine and other hydraulic mechanisms are designed for auxiliary opera- 
tions including directional movement of roof support sections, their leveling off and backlash overlapping.

The control of powered roof support sections can be: manual remote control from the adjacent section or remote central control imposed on the drift; automated group or automated remote from the central control, including the use of telemechanical information and diagnostics based on microprocessor technology.

Automated control systems of the powered roof support, winning machine and face conveyer create real prerequisites for conducting the process of coal mining without the constant presence of workers in the working face.

Currently, extracting seams having thickness from 0,7 to $5 \mathrm{~m}$ is impossible without applying the power roof support. The real area of using powered supports is clearly defined, and the variety of geological conditions while extracting seams of different thickness made the engineers design different types of powered roof supports adjusted to work not only in favourable conditions but also in complex mining and geological conditions specified by roof rocks which are hard to be broken and weak and unstable roof rocks or soil.

Confining pressure changes across the width of the working space and roof support has uneven loads. Therefore, the construction and parameters of the support should provide rational distribution of support resistance along the width of the working space.

Section resistance to roof lowering and, in particular, along the whole long face is of a variable value. And most of the time, sections can operate with the resistance lower than the nominal one. Since the roof support is designed in terms of specified operating pressure (all the costs spent on creating the roof support are calculated based on this condition), and it is operated with alternative pressure, the concept of roof support use should be introduced.

In order to improve the efficiency of the use of powered roof supports and expand their application within the seams with unstable and difficult to be broken roof rocks, the re- search in the following areas is carried out: increasing nominal pressure of the initial thrust and equipping supports with indicators to ensure the convergence of roof support working parameters of actual and project performance; improving the characteristics of rack-mount relief valves, hydraulic prop valves and sealing devices to increase the reliability of the seal cavity of hydraulic props of high pressure and protect them from overloading because of sudden roof lowering; creating the systems of active counterfort to provide the interaction of roof rocks sections with roof support sections and in the process of their relocation; developing the roof supports with adjustable working-resistance to roof support lowering; radical improvement of the hydraulic drive of powered roof supports [2].

One of the reasons to decline technical and economic indices of the stoping process of slope and steep coal seams is a loss of stability and direction of powered support movement in the spatial system "coal seam - powered roof support - winning machine - conveyor". This is particularly relevant issue for mines, reworking the mine fields, where the use of powered highly performed complexes of a new generation is economically inadvisable, and the application of existing complexes of purification equipment requires scientific justification of introduced constructive design changes. It especially concerns standard mechanized hydraulic roof supports M97, M98, and others.

A distinctive feature of the design of this type of equipment is that the set consists of two half-sections, and supports have a small contact surface with the soil formation compared to the aggregated roof supports. Additionally, when shifting a complete one-half section in relation to the second one, the hanging usually takes place due to elastic constraints of the other. In both cases, there is a problem of set stability loss and even its overturning on the face or tipping on its side with the adjacent sections. In this regard, our research can serve as a basis for the creation of new types of powered roof supports or other mechanized devices, providing maximum sta- 
bility for a set or for a number of longwall face sections. However, the creation and introduction of new machines and devices is constrained by insufficient study of equipment sustainability, lack of methodology for its calculation and the selection of operating parameters. Therefore, the problem of stability studies in terms of complete roof support sections is relevant.

Proceeding from this and depending on the operating conditions three cases of roof support operation can be considered:

- two-half-completed section rests in the soil layer on the round flat support of small area;

- two-half-completed section rests in the soil layer on the round flat support of small area by special welded construction increasing the contact area with the soil;

- three-half-completed section rests in the soil layer on the round flat support of small area by special welded construction increasing the contact area with the soil.

The third case has great prospects as the most excluding above mentioned problems.

\section{STABILITY CALCULATION OF A POWERED HYDRAULIC ROOF SUPPORT SET}

Set (section) stability is fixed (static or in the process of advancing) and it is the possibility to maintain its nominal spatial position relatively to the wall rocks and the face, where normal operation of powered support roof is provided under the effect of external and internal forces.

It is necessary to distinguish the following main types of stability losses: [2] section support elements indentation into the roof section or soil; stability loss of sliding sections during the process of their relocation; transverse (lateral) section rollover towards the side of seam dipping.

Note:

- moving the section towards the goaf in case of using complete roof supports fails because hydraulic cylinders of advancing conveyer are connected structurally with the set;
- longitudinal rollover of the set section towards the face is almost impossible since there is no protection fence in the roof supports of types M 97 and M98 [1].

General questions of calculating stability of the roof support set is determined by 12.44.013-76 RTM, whereby the sets in each proposed case should possess definite values of stability.

For the case of assessing the sustainability of two-half-section set during its advance the following schemes are usually considered:

a) the possibility of slipping when shifting (Fig. 1).

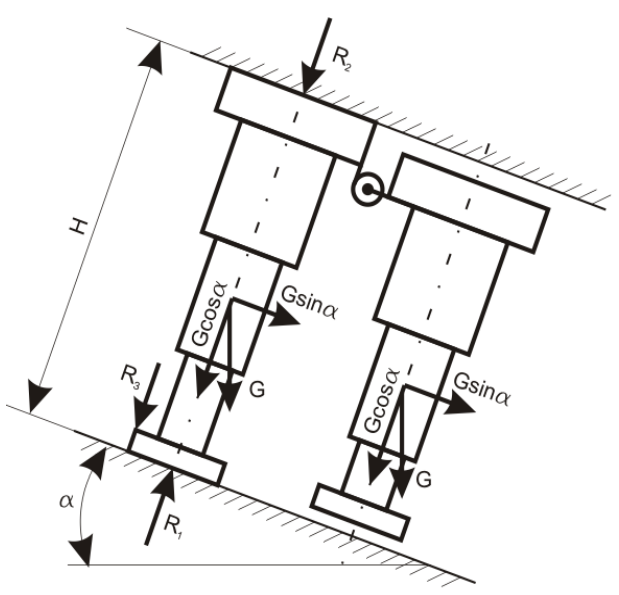

Fig. 1. The calculation scheme for determining roof support stability in the case of slipping probability when advancing

In this case, the section stability factor to slipping while section advancing and its discharge to prop efforts will be

$$
n=\frac{f_{1} G \cdot \cos \alpha+R_{2}\left(f_{1}+f_{2}\right)+R_{3} \cdot f_{3}}{G \cdot \sin \alpha} .
$$

b) section stability factor to the cross section (side) rollover under the effect of nominal loads on section $R$ is determined according to the calculated scheme (Fig. 2), from expression

$$
n=\frac{(R+G) \cdot a \cdot \cos \alpha+R_{3}(a+b)+R \cdot f_{1} \cdot H \cos \alpha}{\left(G \cdot h_{\text {g.c. }}+R H\right) \sin \alpha} .
$$




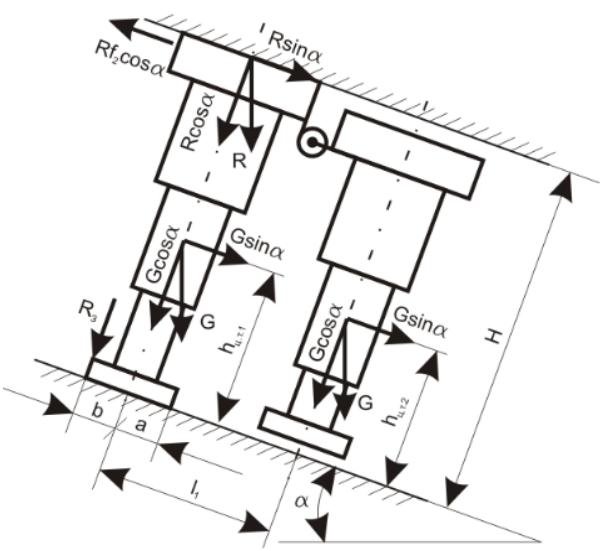

Fig. 2. The calculation scheme for determining the resistance to lateral turnover

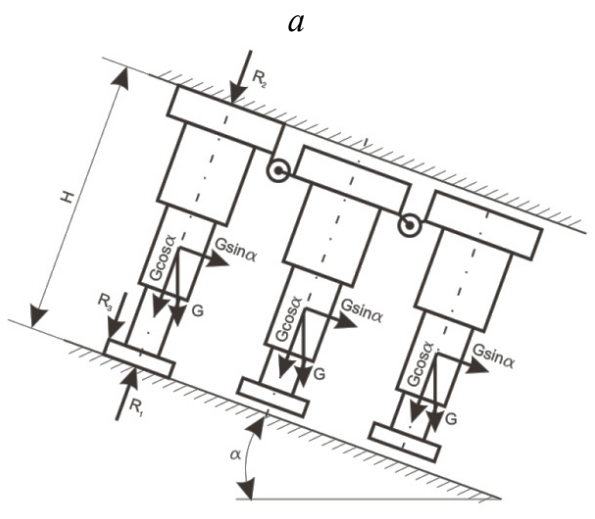

For the case of assessing the stability of three - half-section set under probability of its slipping on seam dip while advancing it is necessary to consider calculated schemes Fig. $3, a$ and $b$. The most favourable position for set advancing is shown on proposed schemes where the extreme sections are located under the prop while the central one is advanced (Fig. 3). The most unfavourable advancing scheme (Fig. 3, b), where the upstream extreme section is located under the prop, and the other two (hanging on the extreme one) are subject to advancing.

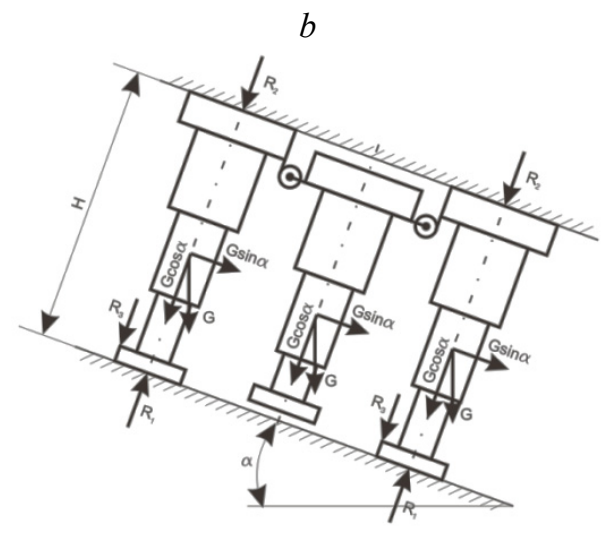

Fig. 3. Schemes determining the set stability factor from slipping on seam dipping while advancing roof support sections

Therefore, the expressions for determining set stability factor to slipping in the case of section advancement will be:

- for the first case

$$
n=\frac{2 f_{1} \cdot G \cdot \cos \alpha+2 R_{2}\left(f_{1}+f_{2}\right)+2 R_{3} \cdot f_{3}}{3 G \cdot \sin \alpha} ;
$$

- for the second case

$$
n=\frac{f_{1} \cdot G \cdot \cos \alpha+R_{2}\left(f_{1}+f_{2}\right)+R_{3} \cdot f_{3}}{3 G \cdot \sin \alpha},
$$

where $G$ - section weight, N; $\alpha$ - seam dip angle, degrees;

$f_{1}, f_{2}, f_{3}-$ friction coefficients of foundation on the soil, overlap on the roof and holding element on the foundation correspondingly;

$R_{2}$ - normal component of roof reaction in the case of one propped section while advancing other two, $\mathrm{N}$;

$R_{3}$ - normal component of the base by retaining element, $\mathrm{N}$.

From obtained expressions it follows that in the second case, the set resistance to slip- 
ping is twice as little.

Set stability factor to the side (lateral) rollover is usually determined by the action of the nominal loading on the section [3]. The calculation scheme for this case is shown in Fig. 4. Here, as in the previous case, two advancing scheme presented in Figure 4, $a$ and $b$ are considered.

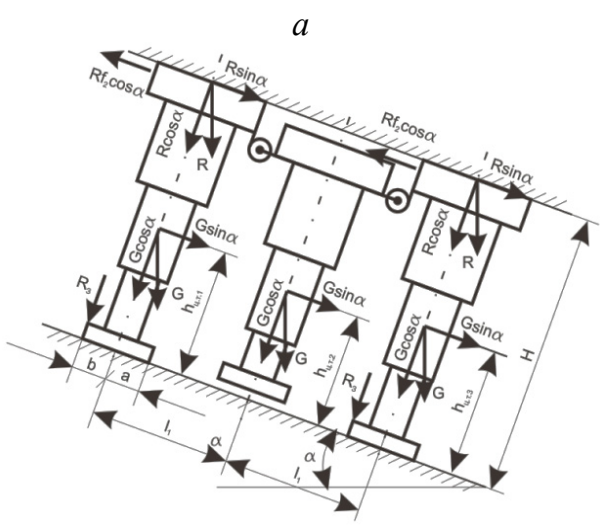

$b$

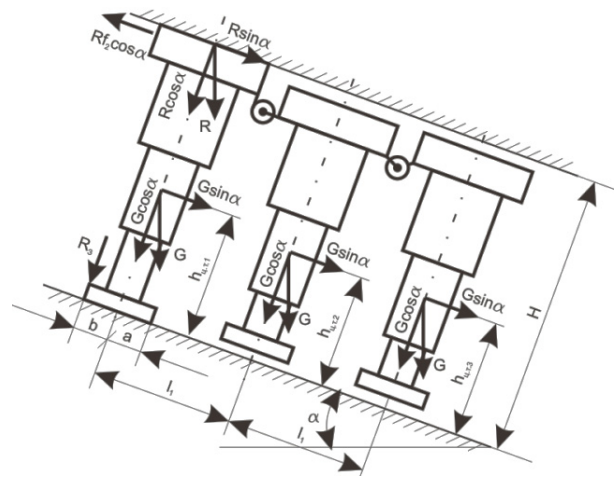

Fig. 4. Schemes to determine set stability factor in case of its turnover towards the direction of seam dip while section advances

Stability factor to the transverse (side) when exposed to overturning the nominal load section is determined from the expression:

- for the first case

$$
n=\frac{R_{3}(a+b)+\left[(R+G) a+R \cdot f_{2} \cdot H\right] \cdot \cos \alpha}{R \cdot \sin \alpha \cdot H+G \cdot \sin \alpha\left(h_{\text {g.c. } 1}+h_{\text {g.c. } 2}+h_{\text {g.c.3 }}\right)+3 G \cdot \cos \alpha \cdot l_{1}} ;
$$

- for the second case

$$
n=\frac{2 R_{3}\left(l_{1}+a+b\right)+\left[2 R \cdot f_{2} \cdot H+\left(l_{1}+a\right)(2 R+3 G)\right] \cdot \cos \alpha}{\left[2 R \cdot H+G\left(h_{\text {g.c. } 1}+h_{\text {g.c. } 2}+h_{\text {g.c.3 }}\right)\right] \sin \alpha .},
$$

where $h_{g . c_{n}}-$ coordinate of gravity centre of corresponding set, $\mathrm{m}$;

$H$ - seam thickness, m;

$a$ - distance from the line of action efforts and with respect to a point where turnover is possible, $\mathrm{m}$;

$b$ - distance from the action line of the restraint force to the middle of the section, $\mathrm{m}$;

$l_{1}$ - distance between the axes of two adjacent sections.
DEPENDENCE ANALYSIS OF STABILITY FACTOR OF SET ROOF SUPPORT ON SLOPE ANGLE OF A STOPE IN THE CONTEXT OF VARIOUS ADVANCE SCHEMES

Based on the expressions (1) - (6) graphic dependences of the stability factor of two- and three-half section roof supports on the slope angle of the stope (Fig. 5) at various schemes of set state while advancing have been obtained.

Considering the graphs (Fig. 5) it can be seen that the factor $n$ of roof support section 
stability to slipping for angles ranging from 0 to $90^{\circ}$ with any scheme of advancing sections (Fig. 6) with two or three sets of semi-sections is more than 1 being within $n=2.8-65$ units. However, when two half-sections (curve 1 in Fig. 5) are strutted and the third one (Fig. 6, $a$ ) is advanced, the value $n$ is approximately twice as big as for one strutted section (Fig. 6, $b$, curve 2 in Fig. 5). Stability zone in the case with two-half-section set (Fig. 6, $b$, curve 3 in Fig. 5) takes approximately a medium position between curves 1 and 2 .

While determining the stability factor $n$ of possible set overturning under the following conditions:

- when angles of working inclination are $\alpha>10^{\circ}$, we can observe that one of halfsections is strutted and two ones are advanced (Fig. 6, b, curve 4);

- when angles of working inclination are $\alpha>65^{\circ}$ and $n<1$, we can observe that two half-sections are strutted and the third one is advanced (Fig. 6, curve 5 in Fig. 5);

- when angles of working inclination are $\alpha>35^{\circ}$ and $n<1$, we can observe two-halfsection set (Fig. 6, $b$, curve 6 in Fig. 5).

Thus, significant advantage is observed while applying a set with three half-sections in coal mining complex operations.

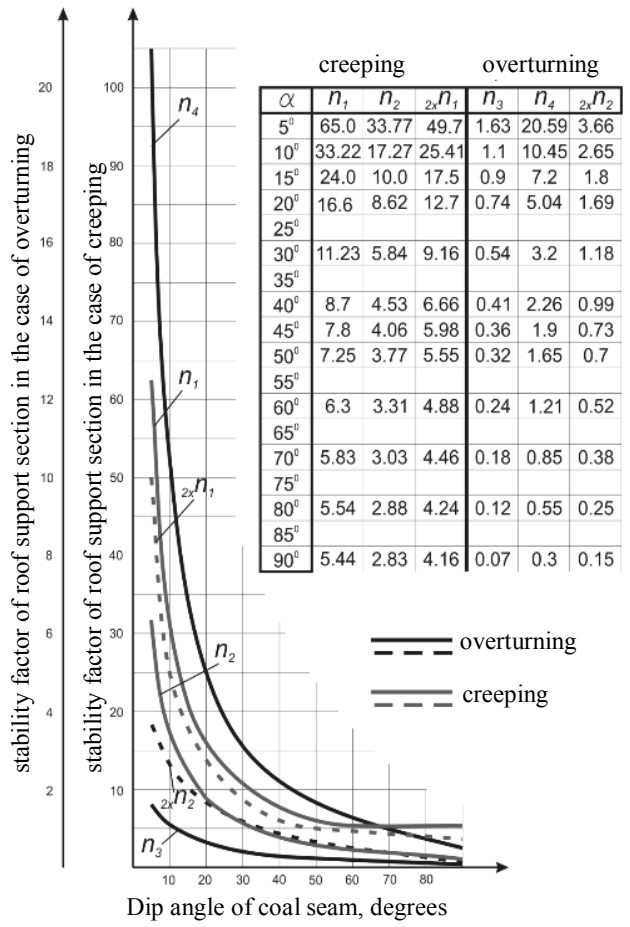

Fig. 5. Graphic dependences of set stability factor on the slope angle of working in the cases of creeping (curves 1, 2,3) and overturning (curves 4, 5, 6) $a$

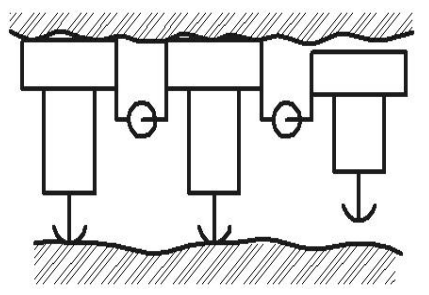

b

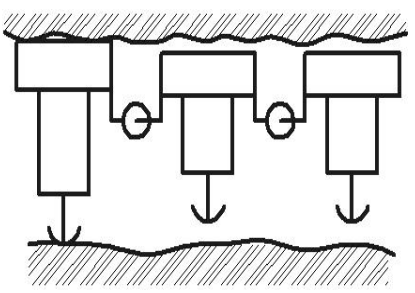

c

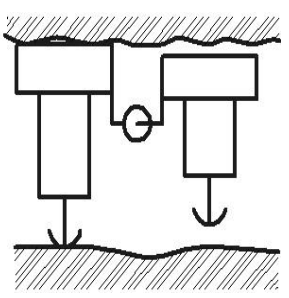

Fig. 6. Schemes of advancing a set of sections

The scheme where two half-sections are strutted and another one is advanced is rather advantageous. This method can be used both for flat and inclined seams ( $\alpha$ is up to $35^{\circ}$ ), and for steep ones ( $\alpha$ is up to $70^{\circ}$ ) in the case of using any narrow-web shearers with holding devices as a winning machine. That is, it extends their application range twice ( $\alpha$ ranges from 0 to $70^{\circ}$ ). 


\section{CONCLUSIONS}

Due to the studies of roof support section stability there have been obtained results that allow to determine the stability factor required for safe operation of the roof support with two or three half-sections depending on geo- logical conditions.

Hydraulic powered support with three half-sections can be applied at enterprises involving into steep seam mining.

The calculations and graphical dependences demonstrated the correctness of approved technical solutions.

\section{REFERENCES}

1. PTM 12.44.005-76. Крепи механизированные. Расчет устойчивости. - М.: Гипроуглемаш, 1976.

2. Хорин В.А. Расчет и конструирование механизированных гидравлических крепей / В.А. Хорин. - М.: Недpa, 1988. - 255 c.

3. Гребенкин С.С. Выбор методики и расчет устойчивости и направленности передвижения секций механизированной крепи на наклонных угольных пластах / [С.С. Гребенкин, В.И. Зензеров, А.С. Гребенкина, И.В. Шипунова] // Школа підземної розробки: матеріали мі- жнар. наук.-практ. конф. - Д.: ЛізуновПрес, 2009. C. $412-422$.

\section{ABOUT AUTHORS}

Felonenko Stanislav V. - Ph.D., associate professor of the Department of Mining Machines and Engineering of the National Mining University.

Gubkina Victoria V. - senior lecturer, Department of Foreign Languages of the National Mining University. 
